\title{
Congenital unilateral facial nerve agenesis
}

口)

Figure 1 Clinical photograph of the patient illustrating right facial palsy

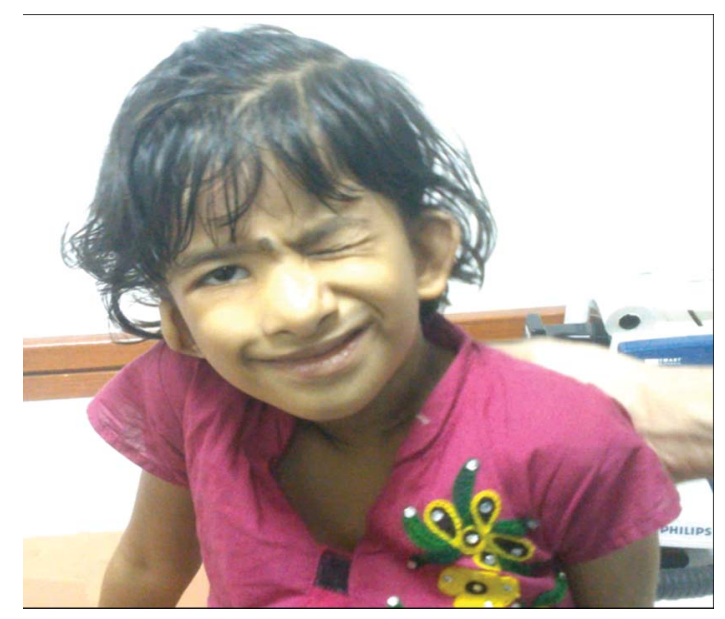

A 7-year-old girl was referred to our department for evaluation of congenital right-sided facial palsy (video on the Neurology ${ }^{\circledR}$ Web site at Neurology.org) and bilateral sensorineural deafness (figure 1). On axial MRI, right facial nerve is not visualized in the cerebellopontine angle cistern with bilateral hypoplastic cochlea. On axial high-resolution CT (HRCT), labyrinthine and tympanic segments of the right bony facial canal are thin and hypoplastic. The mastoid segment of right facial canal is absent on coronal HRCT (figure 2). Congenital facial palsy due to facial nerve agenesis is very rare. ${ }^{1}$ Causes include intrauterine/perinatal trauma and developmental conditions including Möbius syndrome. Unilateral involvement may be secondary to early intrauterine ischemic or traumatic insult.

Abhishek R. Keraliya, DNB, Prashant S. Naphade, MD, DNB

From the Department of CT/MRI, ESIC Hospital, Mumbai, India.

Author contributions: Dr. Abhishek: concepts, design, definition of intellectual content, literature search, data acquisition, data analysis, manuscript preparation, manuscript editing, manuscript review, and guarantor. Dr. Prashant: concepts, design, definition of intellectual content, literature search, data analysis, manuscript editing, and manuscript review.

Study funding: No targeted funding reported.

Disclosure: The authors report no disclosures relevant to the manuscript. Go to Neurology.org for full disclosures.

Correspondence to Dr. Keraliya: abhishekkeraliya@gmail.com

1. Jervis PN, Bull PD. Congenital facial nerve agenesis. J Laryngol Otol 2001;115:53-54. 
Figure 2 Axial DRIVE

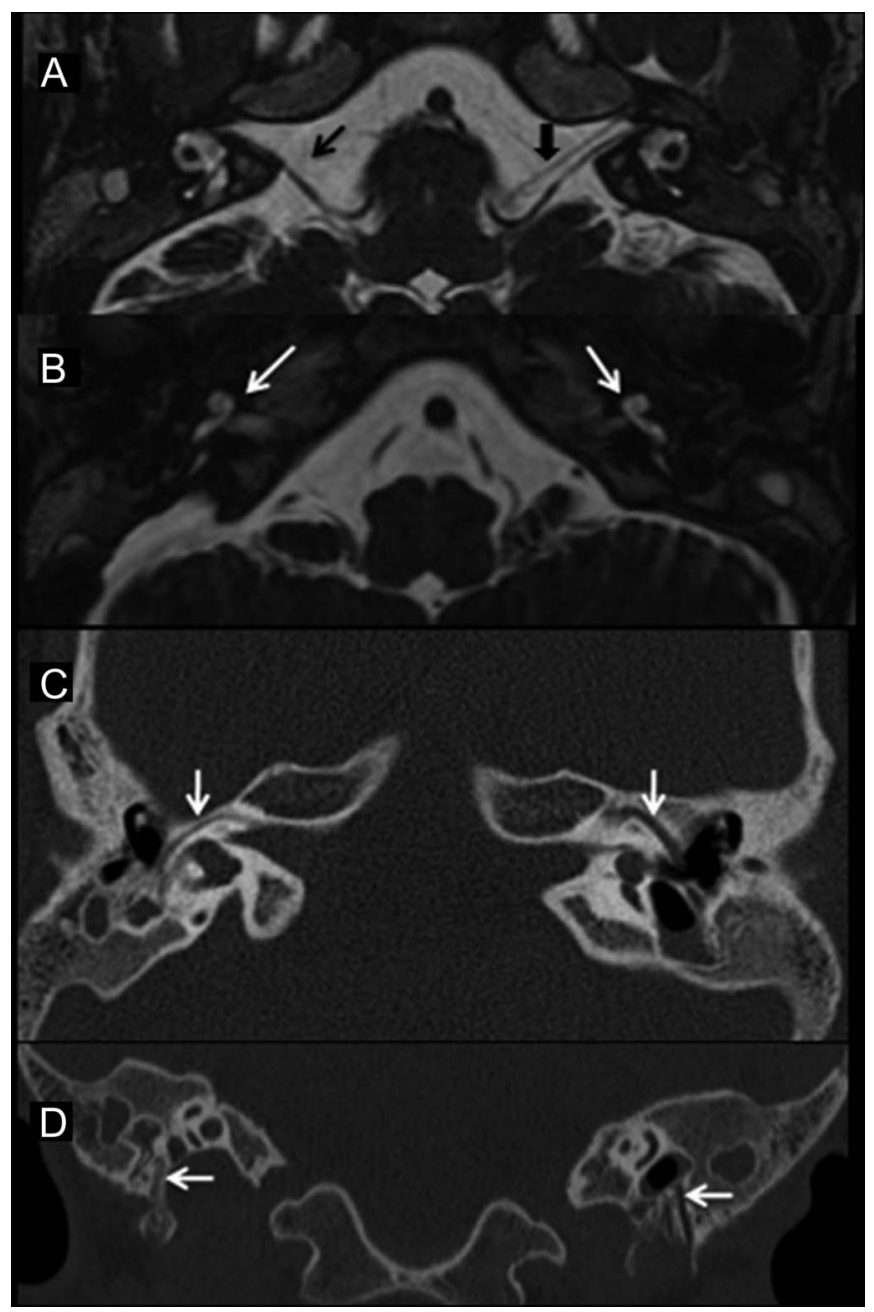

Three-dimensional T2-weighted-driven equilibrium radiofrequency reset pulse image (A) reveals nonvisualization of right facial nerve in cerebellopontine angle cistern, suggestive of agenesis (thin arrow). The left facial nerve is normal (thick arrow). Axial DRIVE image (B) at the level of cochlea reveals small second turn and absent third turn of cochlea on both sides, suggestive of cochlear hypoplasia. Tympanic segment of right bony facial canal is hypoplastic on axial high-resolution CT (HRCT) (C) with nonvisualization of mastoid segment on coronal HRCT (D).

\section{Free Michael J. Fox DVD, Video on Parkinson's Disease}

The AAN and the American Brain Foundation present actor and Parkinson's disease patient Michael J. Fox hosting Parkinson's Disease: A Guide for Patients and Families. This new patient education video is now available free to members and the public, either on DVD or online. The free DVD can be ordered while supplies last by visiting AAN.com/view/PatientEducationVideos or calling (800) 879-1960. The video can be viewed online at YouTube.com/AANChannel with other patient education DVDs produced by the AAN. 


\section{Neurology}

\section{Congenital unilateral facial nerve agenesis}

Abhishek R. Keraliya and Prashant S. Naphade

Neurology 2014;82;2252-2253

DOI 10.1212/WNL.0000000000000527

\section{This information is current as of June 16, 2014}

\section{Updated Information \& Services}

\section{Supplementary Material}

\section{References}

Subspecialty Collections

Permissions \& Licensing

\section{Reprints}

including high resolution figures, can be found at: http://n.neurology.org/content/82/24/2252.full

Supplementary material can be found at: http://n.neurology.org/content/suppl/2014/06/15/82.24.2252.DC1

This article cites 1 articles, 0 of which you can access for free at: http://n.neurology.org/content/82/24/2252.full\#ref-list-1

This article, along with others on similar topics, appears in the following collection(s):

\section{All Pediatric}

http://n.neurology.org/cgi/collection/all_pediatric

\section{Audition}

http://n.neurology.org/cgi/collection/audition

CT

http://n.neurology.org/cgi/collection/ct

MRI

http://n.neurology.org/cgi/collection/mri

Information about reproducing this article in parts (figures,tables) or in its entirety can be found online at:

http://www.neurology.org/about/about_the_journal\#permissions

Information about ordering reprints can be found online:

http://n.neurology.org/subscribers/advertise

Neurology ${ }^{\circledR}$ is the official journal of the American Academy of Neurology. Published continuously since 1951, it is now a weekly with 48 issues per year. Copyright @ 2014 American Academy of Neurology. All rights reserved. Print ISSN: 0028-3878. Online ISSN: 1526-632X.

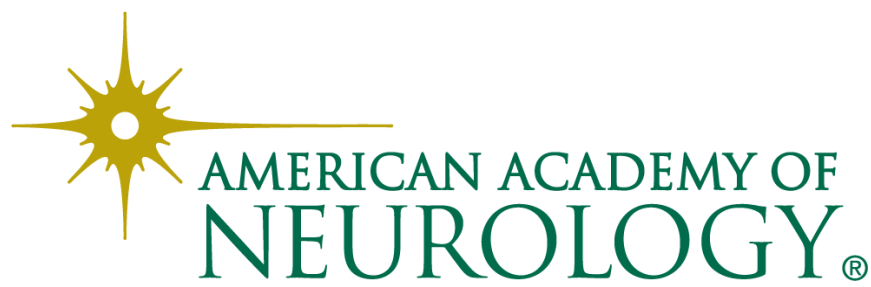

